\title{
Engellilerin Turizm Kısıtları ve Turist Olma Niyeti İlişkisinde Aracı Değişkenler: Motivasyon Gücü ve Öğrenilmiş Çaresizlik
}

Mediating Variables in the Relationship betweeen Tourism Constraints of People with Disabilities and Their Travel Intention: Strength of Motivation and Learned Helplessness

\author{
Beykan ÇizEL*, Rabia Bato ÇizEL** \\ * Doç. Dr., Akdeniz Üniversitesi, Turizm Fakültesi, Turizm İşletmeciliği Bölümü, 07058, Arapsuyu, Antalya. \\ E-posta:beykan@akdeniz.edu.tr \\ ** Doç. Dr., Akdeniz Üniversitesi, İ̈BF, Çalışma Ekonomisi Bölümü, 07058 Arapsuyu, Antalya. \\ E-posta: rabiacizel@akdeniz.edu.tr
}

\section{MAKALE BILGILERI}

Makale işlem bilgileri:

Gönderilme tarihi: 23 Ekim 2013

Birinci değerlendirme: 23 Ocak 2014

İkinci değerlendirme: 28 Şubat 2014

Kabul: 2 Mart 2014

Anahtar sözcükler:

Engelliler, Turizm kısıtları,

Motivasyon gücü, Öğrenilmiş

çaresizlik, Turist olma niyeti.

\section{ARTICLE INFO}

Article history:

Submitted: 23 October 2013

Resubmitted: 23 January 2014

Resubmitted: 28 February 2014

Accepted: 2 March 2014

Key words:

People with disabilities, Tourism

constraints, Strenght of motivation

and learned helplessness.

\section{ÖZ}

Bu çalışmanın amacı engelli bireylerin turizm kısıtları ile turist olma niyeti ilişkisi ve bu ilişkide psikolojik değişkenlerin (turist olma motivasyonu gücü ve öğrenilmiș çaresizlik) aracılık rolünü incelemektir. Bu bağlamda, turizm kısıtları ve turist olma niyeti ilişkisinde, öğrenilmiş çaresizlik ilk kez motivasyon gücünün sosyal ve psikolojik öncülü olarak öngörülmüş ve bu iki değişken ilk kez bir model içerisinde birlikte kullanılmıştır. Ölçüm aracını içeren anket, sistematik örnekleme yöntemi ile seçilen 239 engelliye uygulanmıștır. Değișkenler arası ilișkiler ve aracılık etkilerini test etmek için yapısal eşitlik modeli kullanıımıştır. Yapılan analizler, turist olma niyeti ile turizm kısıtları arasındaki iliş̧ide sözü edilen iki psikolojik değişkenin kısmen aracılık etkisini göstermektedir. Bulgular engellilerin karşılaștıkları seyahat engelleri nedeniyle kendilerini çaresiz hissettikleri zaman turist olma motivasyonu gücünün düştüğünü ve dolayısıyla turizme katılma niyetinin azaldığını ortaya koymaktadır. Araştırma modelinde bu yönde ortaya konan görgül kanıt, ilgili yazın için yeni ve önemli bir katkıdır.

\section{GiRiş}

Turizm, engelli bireylerin fiziksel, psikolojik ve ruh sağlığının gelişimine katkıda bulunabilir. Bunun ötesinde, turizm sosyal ilişki becerisinin kurulması ya da sürdürülmesi ve başkalarını anlama kapasitesinin arttırılması, ufkun genişlemesi, kültürler arası etkileşimin gelişmesi, yeni bilgilerin öğrenilmesi için kişilere fırsatlar sağlayarak bireylerin kişisel gelişim ve yaşam kalitesini arttırabilir. Toplumsal açıdan ise turizm, engellilerin sosyal uyum masraflarının azaltılması, sosyal bütünleşme ve sosyal eşitliğin hayata geçirilmesi dâhil olmak üzere pek çok fayda sağlayabilir.
Birleşmiş Milletler'e göre, dünya nüfusunun yaklaşık \%10'u, diğer bir deyişle yaklaşık 700 milyon insan engellidir. Devlet İstatistik Enstitüsü tarafından 2002 yılında gerçekleştirilen Türkiye Engelliler Araştırması' nın verilerine göre ülkemizdeki engelli nüfusun toplam nüfusa oranı $\% 12,29$ olarak saptanmıştır. Bu orana göre, ülkemizde yaklaşık 8 milyon engellinin bulunduğu tahmin edilmektedir. Bu rakamlar dünyada ve ülkemizde ciddi bir engelli turist potansiyelinin olduğunu göstermektedir. Ülkemizdeki engellilerin turist olma niyetleri güçlü olursa turizm işletmelerimizin bu potansiyelden yararlanma düzeyi artacaktır. Engellilerin dünya 
genelinde olduğu gibi Türkiye'de de turizme katılım arzularının fark edilmesi ve bu pazarın kârlı bir niş pazar olarak görülmesi, engelli turizmine yönelik ilgiyi arttırmıştır. Artan bu ilgi akademik yazında da kendisini hissettirmiştir. Uluslararası yazın incelendiğinde, engellilerin seyahat engelleri (Smith 1987; Cavinato ve Cuckovich 1992; Abeyraine 1995), seyahat karar alma süreçleri (Smith 1987; Shaw ve Coles 2004), tatil anlamları, motivasyonları, deneyim ve memnuniyetleri (Jakson vd. 1993; Darcy 2002; Yau vd. 2004; Daniels vd. 2005), seyahat acentaları rolündeki algılar (McKercher vd. 2003) seyahat niyetini etkileyen faktörler (Lee vd. 2011; Alexandris vd. 2011) gibi farklı konu başlıklarında çalışmalara rastlamak mümkündür. Ulusal yazında ise engellilere yönelik turizm imkânlarının değerlendirilmesine yönelik az sayıda çalışma göze çarpmaktadır (Artar ve Karabacakoğlu 2003; Öztürk vd. 2008).

Uluslararası yazında yapılan çalışmalarda, araştırmacıların önemle üzerinde durdukları konulardan biri, engellilerin turizm kisitlarının belirlenmesidir. Engelli olanlar olmayanlara göre doğası ve şiddeti farklı olan kısıtlamaları tecrübe edebilirler. İlgili yazında turizm kısıtları ile engellilerin turizm faaliyetlerine katılma niyeti arasında doğrudan negatif bir ilişki olduğu sıkça tanımlanır (Smith 1987; Jackson 1993) ve bu yüzden de engelli kişilerin turizme katılımlarını artırmak için, bu tür engellerin ortadan kaldırılması önerilir (Israeli 2002; McKercher vd. 2003; Öztürk vd. 2008). Ancak, sözü edilen doğrudan kuvvetli negatif ilişkinin varlığı görgül araştırmalar ile kanitlanamamıştır.

Engellilerin karşılaştığ seyahat engellerini belirlemeye çalışan Smith (1987) turizm kısıtlarını içsel, çevresel ve etkileşimsel olarak üç boyutta ele alırken, Gladwell ve Bedini (2004) ise engellilerin turizm kısıtlarını psikolojik, sosyal ve duygusal engeller olarak sınıflandırmıştır. Engellilerin turizm kısıtlarını, bireysel, kişilerarası ve yapısal olmak üzere üç boyutta sınıflandıran çalışmalarda vardır (Crawford ve Godbey 1987; Crawford vd. 1991). Yapılan tanımlarda farklıliklar olmakla beraber ortak olan fikir, turizm faaliyetlerine katılma yönündeki engellerin bu tür faaliyetlere katılımı azaltan ve katılımcıların zevk almalarını engelleyen faktörler olduğudur. Yukarıda sözü edilen çalışmalar nitel yöntemlere dayalı olarak, engellilerin turizm kısıtlarının neler olduğuna yönelik tipolojiler ortaya koymuşlardır. Temel saptamaları ve katkıları ise sözü edilen kısıtları ortadan kaldırmanın, engelli bireylerin turizm faaliyetlerine katılma niyetlerini doğrudan veya dolaylı olarak artıracağı yönündedir. Ancak, seyahat kısıtları ile seyahat niyeti arasındaki kuvvetli doğrudan ilişkinin varlığı, yapılan görgül araştırmalarda saptanamamıştır (Alexandris vd. 2002; Stalp 2006; Alexandris vd. 2007; Son vd. 2008; Lee vd. 2011). Sözü edilen araştırmalarda yazarlar, seyahat kısitları ve seyahat niyeti arasındaki mantıksal ilişkiyi kuvvetlendiren aracı değişkenleri ekledikleri modelleri, yapısal eşitlik modelleme yöntemi ile test etmişlerdir. Alexandris vd. (2011) motivasyon gücünü aracı değişken olarak kullanırken, Lee vd. (2011) ise çalışmalarında öğrenilmiş çaresizliği aracı değişken olarak kullanmışlardır.

Smith (1987), engelli turistlerin karar verme sürecinde çeşitli engellerle karşılaşabileceklerini ancak seyahate katılmak için nihai kararlarında bu engellerin etkisinin çaresizlik algıları da dâhil olmak üzere bir dizi kişisel özelliklere bağlı olabileceğini ifade etmektedir. Seyahat niyeti, kısmen, karar alma sürecinin çeşitli aşamalarında mevcut olabilen çeşitli engellerin üstesinden gelerek oluşturulur. İlgili yazın, engelli kişilerin turizme katılım karar1 verirken doğrudan seyahat engellerinin etkili olduğu saptamasını yetersiz bulmakta ve seyahat kararını etkileyen diğer değişkenlerin de incelenmesi gerektiğini belirtmektedir (Smith 1987; Lee vd. 2011; Alexandris vd. 2011). Seyahat karar1; motivasyon, yaşam tarzı ve değerler, kişilik ve sosyoekonomik özellikler gibi karmaşık bir dizi içsel değişkenlere dayalıdır (Pearce 2005). Ayrıca seyahat kararı veren birey, dış engellerle de karşılaşabilir. Dahası bireyin yeteneğinin (Alegre vd. 2010) daha eleştirel değerlendirilmesi, turizm faaliyetlerine katılma kararında önemli bir rol oynar. Bu bağlam$\mathrm{da}$, seyahat kısıtlamaları ve engelli kişilerin seyahate katılmaları arasındaki ilişki, en azından bazı durumlarda kişisel özellikler ile şartlandırıldığında dolaylı olma olasılığını daha da yükseltir. Böyle bir tartışma konusu en az iki teori ile desteklenir. Bunlar uzlaşma teorisi ve öğrenilmiş çaresizlik kuramidır.

Öğrenilmiş çaresizlik (Seligman 1975), kişinin herhangi bir durumda çok sayıda başarısızlığa uğrayarak, ne yaparsa yapsın hiçbir şeyin değişmeyeceğini, olayların kendi kontrolünde olmadığını, o konuda bir daha asla başarıya ulaşamayacağını düşünüp, yeniden deneme cesaretini kaybetmesi olarak tanımlanır. Öğrenilmiş çaresizliğe göre; 
bireylerin çevrelerini kontrol etmek için yaptıkları başarısız girişimlerinden (kendi engelleri nedeniyle) kaynaklanan olumsuz sonuçları (seyahat edememe) görmek, bu gibi durumların gelecekte de olabileceğini ve sonrasında da bu kişilerin gelecekteki katılım çabalarını bırakabileceklerini ifade eder. Öğrenilmiş çaresizliğin, engelli bireylerin turizme katılım niyeti ile turizm kısitları arasında bir aracı değişken olabileceği tezi görgül olarak test edilmiş (Lee vd. 2011) ve istatistiksel olarak anlam11 bulunmuştur.

Engellilerin turizm kısıtları ile turist olma niyetleri arasındaki doğrudan ilişkinin kuvvetli olmaması durumunu Jackson ve diğerleri (1993), uzlaşma teorisine dayandırdıkları turizm kısıtları ile başa çıma stratejileri ile açıklamaya çalışmaktadırlar. Bu teoriye göre, bireyler turizm faaliyetlerine katılma sürecinde engeller ile karşı karşıya kaldıklarında pasif değildir. Bunun yerine muhtemel alternatifleri göz önüne alarak, proaktif olarak bu engeller ile başa çıkmaya çalışırlar. Yazarlar, turizm kısıtları ile başa çıkma stratejilerinin başarısının, kişinin motivasyon gücü ve onun kisıtlar ile etkileşimi ile belirlendiğini vurgular. Bu tezden hareketle motivasyon gücünün turizm kısıtları ile turist olma niyeti arasında aracı etkisi, birkaç çalışmada incelenmiştir (Hubbard ve Mannell 2001; Alexandris vd. 2002; Stalp 2006; Alexandris vd. 2007; Son vd. 2008; Alexandris vd. 2011).

$\mathrm{Bu}$ çalışmanın amacı ise engelli bireylerin seyahat engelleri ile turist olma niyeti ilişkisi ve bu ilişkide psikolojik değişkenlerin (turist olma motivasyonu gücü ve öğrenilmiş çaresizlik) birlikte yaratmış olduğu aracılık rolünü incelemektir. Bu bağlamda, turizm kısıtları ve turist olma niyeti ilişkisinde, ilk defa öğrenilmiş çaresizlik, motivasyon gücünün sosyal ve psikolojik öncülü olarak öngörülmüş ve bu iki değişken ilk kez bir model içinde birlikte kullanılmıştır.

Yukarıda özetlenen yazında, engellilerin seyahat kısıtları ile seyahat niyeti arasındaki ilişkinin incelenmesinde turist olma motivasyonu gücü ve öğrenilmiş çaresizlik, ayrı ayrı aracı değiş̧kenler olarak modellerde kullanılmıştır. Bu çalışmada ise ilk defa öğrenilmiş çaresizlik ve motivasyon gücü, kurama dayalı hipotezlerle birlikte bir model içinde ilişkilendirilmiş ve engellilerin seyahat niyeti ile seyahat kısıtları arasındaki ilişkiyi açıklamadaki kısmi ve tam aracı değişken olma özelliği test edil- miştir. Bununla birlikte, turizm kısıtları ve turizm aktivitelerine katılım niyeti ilişkisinde öğrenilmiş çaresizlik, motivasyon gücünün sosyal ve psikolojik öncülü olarak öngörülmüştür. Diğer bir deyişle, seyahat kısıtları ile seyahat niyeti ilişkisinde belirleyici olduğu vurgulanan ve farklı modellerde tek tek incelenmiş olan iki psikolojik değişkenin bir arada seyahat niyetini açıklamadaki rolü ve gücü test edilmiştir. Ayrıca, öğrenilmiş çaresizliğin dolaylı olarak motivasyon gücü üzerinden turist olma niyetine etkisi ilk defa görgül olarak test edilecektir.

Diğer taraftan, ulusal turizm yazınında engellilere yönelik araştırma sayısı yok denecek kadar azdır. Yapılan araştırmalarda (Artar ve Karabacakoğlu 2003; Öztürk vd. 2008) ise betimsel istatistik analizlerle, engellilere yönelik turizm imkânları değerlendirilmiştir. Turizm arz unsurlarının değerlendirildiği bu araştırmaların paralelinde engelli turist talebinin özelliklerine ve seyahat niyetini etkileyen unsurların incelenmesine de ihtiyaç vardır. Bu çalışma, engelli talebinin özelliklerini ve bakış açısını yansıtmaktadır. Bu notadan hareketle ilişki analizlerine dayanan istatistiksel yöntemlerin betimsel analizlerle elde edilecek bulguların değerlendirilmesine ve yorumlanmasına katkı sağlayacağı kanaatini taşımaktayız. En önemlisi engellilerin seyahat niyetini etkilediği öne sürülen seyahat engelleriyle karşılaşmaları durumunda, bu engellerle baş etmeye yönelik başarısız çabalarının engelli bireylerin psikolojileri (motivasyon gücünü ve öğrenilmiş çaresizlik) üzerinde tahribat yaratıp yaratmadığına yönelik görgül bulgular sunulmuştur. Bu görgül bulgular 1şığında engelli bireylerin seyahat davranışını etkileyen psikolojik faktörlerin etkileri, nitel araştırma yöntemlerinin de katkısıyla daha ayrıntılı incelenebilir.

\section{YAZIN TARAMASI}

\section{Engellilerin Turizm Kısıtları ve Turist OIma Niyeti}

Turizm faaliyetlerine katılma niyeti, kısmen karar alma sürecinin çeşitli aşamalarında mevcut olabilen içsel (seyahat arzusu eksikliği, seyahat etme yetkinliği eksikliği) ve kişilerarası farklı kısıtlamaların (arkadaş eksikliği, zaman eksikliği vb.) üstesinden gelerek oluşturulur (Lee vd. 2011). Turist olma niyeti oluşumu sürecinde, engelli olanlar olmayanlara göre doğası ve şiddeti farklı olan kısıtlamaları tecrübe edebilirler (Smith 1987). İlgili yazın kronolojik olarak incelendiğinde, önceleri boş zaman de- 
ğerlendirme kısıtları kapsamında yapılan çok sayıda çalışmaya rastlamak mümkündür (Crawford ve Godbey 1987; Crawford vd. 1991; Jackson 1993; Alexandris ve Carroll 1997).

Engelliler ve turizm kısıtları bağlamında incelendiğinde ise özellikle son on yıl içerisinde pek çok çalışma yapılmıştır (Cavinato ve Cuckovich 1992; Abeyraine 1995; Darcy 2002; Israeli 2002; Burnett ve Baker 2011; Lee vd. 2011). Engellilerin turizm engellerini belirlemeye çalışan Smith (1987), turizm engellerini içsel, çevresel ve etkileşimsel engeller olarak üç boyutta ele almıştır. İçsel engeller; bilgi eksikliği, sağlıkla ilgili problemler, sosyal etkisizlik, fiziksel ve psikolojik bağımlılık gibi boyutlardan oluşur. Çevresel engeller ekolojik kısıtlamalar, ulaşım kısıtları, kurallar ve yönetmeliklerden oluşur. Etkileşimsel engeller ise beceri uyuşmazlığ ve iletişim engellerinden oluşur.

Turizm kısıtları, turizmle ile ilgili faaliyetlere katılımı engelleyen ve azaltan faktörlerden oluşmaktadır. Örneğin, Gladwell ve Bedini (2004), psikolojik, sosyal ve duygusal engeller içerisinde k1sıtlamaları sınıflandırmıştır. Crawford ve Godbey (1987) ile Crawford ve arkadaşları (1991) engelleri üç boyutla; (i) kişinin kendi zihninde oluşan (içsel); (ii) kişiler arası ve (iii) yapısal (bağlamsal) olarak tanımlamışlardır. İçsel engeller kişinin kendi zihninde oluşturduğu kısıtlamalardır. Bireylerin dini inançları ve ruh halleri, davranışları, kişisel faktörler de dâhil psikolojik durumları ile ilgilidir. Yapısal kısıtlamalar; para, zaman ve firsat eksikliğini içerirken kişiler arası kısıtlamalar aile üyeleri, arkadaşlar, meslektaşlar ve komşular gibi başkalarıyla sosyal etkileşimden ortaya çıkar. Turist olmak isteyen birey sözü edilen tüm bu kısıtlamaların sırayla üstesinden gelmeye çalışır. Başarılı olunursa sonuç, turizm faaliyetlerine katılmak olur (Crawford vd. 1991).

Bazı turizm araştırmacıları (Fleischer ve Seiler 2002; Hinch ve Jackson 2000; Nyaupane vd. 2004) turist olanlardan turist olmayanları ayırmanın çok çeşitli nedenlerini anlamak için turizm kısıtlamalarını incelemişlerdir. Ayrıca araştırmacılar engellilerin karşılaştığı seyahat kısıtlamalarını belirlemeye çalışmıştır. (Israeli 2002; McKercher vd. 2003; Shaw ve Coles 2004; Yau vd. 2004; Daniels vd. 2005; Bi vd. 2007). Çalışmalarda ortaya çıkan sonuçlar ve tartışmalar incelendiğinde, engellilerin turizm aktivitelerine katılım niyeti ve turizm kısıtlamaları arasında ters yönlü bir ilişkinin varlığı göze çarpar. Verilen bilgiler ışığında aşağıdaki hipotez geliştirilmiştir:

Hipotez 1: Engellilerin algıladıkları turizm kısıtları, turist olma niyetini negatif yönde etkiler.

Engellilerin karşılaştığ dan kalkarsa, turist olma niyetinin artacağ yısıyla turizm faaliyetlerine daha fazla katılacakları yönünde genel bir inanış vardır. Ancak algılanan turizm kısıtları ile davranışsal sonuçları arasında doğrudan bir ilişkinin varlığı ile ilgili bulgular zay1ftır (Kay ve Jackson 1991; Alexandris vd. 2011; Lee vd. 2011). Bu iki değişken arasındaki ilişkinin gücünü arttıracak birçok aracı değişkenden bahsedilir. Bunlar; bireyin durumsal değerlendirmeleri (Alegre vd. 2010), motivasyon gücü (Alexandris vd. 2011) ve öğrenilmiş çaresizliktir (Lee vd. 2011).

\section{Engellilerin Turizm Kısıtları ve Turist Olma Niyeti İlişkisinde Aracı Değişkenler (Motivasyon Gücü ve Öğrenilmiş Çaresizlik)}

Maslow (1943), motivasyonu insan davranışları arkasındaki itici güç olarak tanımlamaktadır. Gnoth (1997) ise motivasyonun davranışın bilişsel ölçülebilir bir parçası olduğunu vurgular. Ajzen (1991), planlı davranış teorisinde motivasyon faktörlerinin tutumu ve dolayısıyla davranışı etkilediğini ve davranışı gerçekleştirmek için insanların sarf ettiği çabanın belirleyicisi olduğunu ifade etmektedir. Alexandris (2011), motivasyonun bilişsel, duyuşsal ve davranışsal sonuçlara yol açtığını ileri sürmektedir. Baloğlu (1999) yapmış olduğu çalışmada motivasyonun bir destinasyonu tekrar ziyaret etme niyetinde belirleyici bir bilişsel unsur olduğunu saptamıştır. Turist karar alma süreci açısından bakıldığında, seyahat motivasyonları bir tatil kararı için bireysel teşvik talep öncülü olarak görülmektedir (Lee vd. 2011). Bunun anlam1, yüksek motivasyona sahip olan turistler boş zaman değerlendirme aktivitelerine katılmak için her türlü seyahat kısıtı ile başa çıkabilirler.

Engellilerin turizm kısıtları ile turist olma niyetleri arasındaki doğrudan ilişkinin kuvvetli olmaması durumunu Jackson ve diğerleri (1993), turizm kısıtları ile başa çıkma stratejileri ile açıklamaya çalışmaktadırlar. Yazarlar uzlaşma teorisine dayandırdıkları görüşlerinde, bireylerin turizm faaliyetlerine katılma sürecinde engeller ile karşı 
karşıya kaldıklarında pasif olmadıklarını ifade etmektedirler. Bunun yerine, muhtemel alternatifleri göz önüne alarak proaktif olarak bu engeller ile başa çıkmaya çalışırlar. Yazarlar turizm kısıtları ile başa çıkma stratejilerinin başarısının, kişinin motivasyon gücü ve onun kısıtlar ile etkileşimi ile belirlendiğini vurgulamaktadırlar. Diğer bir deyişle, bireylerin motivasyon gücü engellerle başa çıkma stratejilerini arttırarak turizm faaliyetlerine katılma niyetini olumlu yönde etkiler. Bu tezden hareketle, motivasyon gücünün turizm kısıtları ile turist olma niyeti arasında aracı etkisi birkaç çalışmada incelenmiştir (Hubbard ve Mannell 2001; Alexandris vd. 2002; Stalp 2006; Alexandris vd. 2007; Son vd. 2008; Alexandris vd. 2011). Alexandris ve arkadaşları (2011) çalışmalarında kendi kaderini tayin teorisine (Deci ve Ryan 2000) dayandırarak test ettikleri turist engelleri, motivasyonun gücü ve turizm aktivitelerine katılım niyeti ilişkisinde turizm kısıtlarını motivasyonun sosyal ve psikolojik öncülü olarak önermişlerdir. Özetle, önceki çalışmalar, algılanan turizm kısıtlarının motivasyon gücünü azaltabileceğini; buna karşın eğer motivasyon gücü artarsa turist olma niyetinin de güçleneceğini, bu anlamda algılanan engellerin niyet üzerindeki olumsuz etkisinin motivasyon gücü ile azaltılabileceğini vurgulamaktadır. Yazından elde edilen bu bilgiler ışığında aşağıdaki hipotezler geliştirilmiştir:

Hipotez 2: Engellilerin algıladıkları turizm kısıtları, turist olma motivasyonu gücünü negatif yönde etkiler.

Hipotez 3: Engellilerin turist olma motivasyonu gücü, turist olma niyetini pozitif yönde etkiler.

Hipotez 4: Engellilerin turist olma motivasyonu gücü, turizm kısıtlarn ile turist olma niyeti ilişkisinde aracı değ işkendir.

Turist olma niyeti ve seyahat kısıtlamaları üzerinde aracı değişkenlerin önemini vurgulayan Lee ve arkadaşları (2011) çalışmalarında öğrenilmiş çaresizlik teorisini (Seligman 1975) kullanmıştır. Yazarlar bu teorinin turizm kısıtları azalmasına rağmen engellilerin turizm faaliyetlerine neden katılmadıklarını açıklamada önemli olduğunu vurgularlar. Teoriye göre (Seligman 1975: 46), eğer bireyin serbest davranması engellenir ise birey istediğiniz şekilde davranmaya daha kararlı hale gelebilir. Sonucun kendi davranışlarından bağımsız olarak gerçekleşebileceğini öğrenen birey, olayın ken- di kontrolünde olmadığını ve gelecekte de kontrol edememe ihtimalinin süreceği endişesini taşır. Sonuç olarak, onların başlangıçta istenilen şekilde davranmasını sağlamak için koşullar değişse bile, bunu başarmak için çalışırken çaresizlik deneyimleri kişileri vazgeçirebilir ve/veya kendilerine olan güvenlerini kaybetmelerine neden olabilir. Bu tür durumlarda, kişiler maruz kaldıkları hoş olmayan ya da zararlı durumlardan kaçınarak, kendilerine yardımcı olmak için fırsatların düzeltilmesine bakılmaksızın çaresizce davranacağını öğrenmiştir. Zaman içinde, atıfsal özellikler, özellikle de kötümser bir açıklama biçiminin varlığı çaresizlik olasılığını etkileyerek bir kişinin bir olaya bakış açısını olumsuza dönüştürerek istenilen sonuçların üretiminde eylemlerin etkisiz olacağ 1 beklentisine yol açabilir. Dolayısıyla, kişi belirli bir aktiviteye artık ne katılabilir ne de katılmaya teşebbüs edebilir. Bu nedenle, öğrenilmiş çaresizlik, kişinin herhangi bir durum üzerinde hiçbir kontrole sahip olmadığını ve yaptıkları her ne varsa bunların boşuna olduğuna inanarak ögrendiği bir psikolojik durumdur.

Öğrenilmiş çaresizlik, engelli veya engelli olmayan kişilerde bazen motivasyonel, bilişsel ve duygusal eksiklikle sonuçlanabilir (Seligman 1975: 55-56). Engelliler turist olmak için davranışlarının sonuca ulaşmada boşuna olduğunu ve isteklerini gerçekleştirebilmede çabalarının başarısız olduğunu görürlerse kaygı ve korku yaşayabilir ve dolayısıyla depresyona girebilirler. Bu durum engellilerin seyahat motivasyonunu ve seyahat niyetini etkileyen önemli bir faktör olabilir. Bu nedenle, öğrenilmiş çaresizlik teorisi engelli kişilerin turizme katılım motivasyonu ve seyahat niyetini incelemede son derece uygun bir değişkendir (Lee vd. 2011). Engelliler bağımsız olarak turizm faaliyetlerine katılmada daha az olanaklara sahiptir ve daha önce turizm faaliyetlerine katılmış olmaları gerçeğine rağmen, karşılaşılan kaçınılmaz engeller turizm deneyimlerinde alınan zevkin azalmasina neden olur. Engellilerden bazılarının seyahat etme motivasyonunun azalması ve seyahat arzusunu tamamen terk etmeleri, öğrenilmiş çaresizliğin olumsuz sonuçlarından biridir. Buna rağmen, engelliler turizme katılımlarında belki daha dikkatli davranabilir ama seyahat arzusundan vazgeçmeyebilir. Ancak, olumsuz turizm deneyimleri oluşmaya devam ederse, en esnek engelli yolcu bile güven kaybı, denetim eksikliği ve seyahat ile ilgili olarak çaresizlik duygusu sergileyerek acı çekebilir (Lee 
vd. 2011). Özetle engelliler çaresizliği öğrenirlerse, turizm ve ilgili faaliyetler için uygun koşullar olsa bile, turizm faaliyetleri içinde yer alma konusunda terreddüt edebilirler. Birey kontrol edememeyi kendinde olmayan ama diğer bireylerde olan özelliklere bağlı olarak görürse bilişsel, duygusal ve motivasyonel eksiklik yaşar.

Yukarıda verilen örneklerden anlaşılacağı gibi, yazında araştırmacıların ilgisine egemen olan engellilerin karşılaştıkları kısıtlamaların türlerini incelemek tartışmasız yeterli değildir. Bu nedenle, seyahat niyeti, turist olma motivasyonu gücü, seyahat kısıtlamaları ve öğrenilmiş çaresizlik arasındaki ilişkinin daha fazla araştırılması ve dikkatlerin bu konulara yöneltilmesi zorunludur. Bu bilgiler doğrultusunda aşağıdaki hipotezler oluşturulmuştur:

Hipotez 5: Engellilerin algiladikları turizm kısıtları, turizm faaliyetlerine katılmalarına ilişkin öğrenilmiş çaresizlik düzeyini negatif yönde etkiler.

Hipotez 6: Engellilerin algıladıkları turizm faaliyetlerine katılmalarına ilişkin öğrenilmiş çaresizlik düzeyi, turist olma motivasyonu gücünü negatif yönde etkiler.

Hipotez 7: Engellilerin turizm faaliyetlerine katılmalarnna ilişkin öğrenilmiş çaresizlik düzeyleri, turist olma niyetini negatif yönde etkiler

Hipotez 8: Engellilerin algiladıklarn turizm faaliyetlerine katılmalarına ilişskin öğrenilmiş çaresizlik düzeyi, turizm kısıtlarn ile turist olma niyeti ilişkisinde aracı değişkendir.

\section{ARAŞTIRMANIN YÖNTEMI}

\section{Örneklem ve Veri Toplama Süreci}

Araştırmaya Ankara, İzmir ve İstanbul illerinde yaşayan ve Altı Nokta Körler Derneği'ne ve Türkiye Sakatlar Derneği'ne kayıtlı toplam 12.237 kişiden sistematik örnekleme yöntemi ile seçilen gönüllü kişilere anket uygulanmıştır. Araştırmaya katılan 239 kişi \%10 hata oranı ve \%90 güven düzeyi ile anakütleyi temsil gücüne sahiptir. Engellilerin illere göre dağılımı Tablo 1'de görüldüğü gibi eşittir. Araştırmada veri toplama aracı olarak anket tekniği kullanılmıştır. Veriler engellilerin yaşadıkları şehirlerde farklı engelli gruplarına (görme-işitsel ve bedensel) göre iletişim eğitimi almış ankatörler tarafından yüzyüze görüşülerek toplanmıştır. Veriler, Akdeniz Üniversitesi Proje Geliştirme ve Araş- tırma Merkezi'nin “Batı Akdeniz Kalkınma Ajansı mali desteği ile Sanayi ve Turizm Sektörlerinin Rekabetçiliğinin Arttırılması 2010 Yılı Mali Destek Programı kapsamında yürüttüğü TR61/10/KAMU/01-68 referans kodlu "Engelsiz Antalya-Engelsiz Turizm Projesi" çerçevesinde gerçekleştirilen proje kapsamında, 2011 yılının Ocak- Mart ayları arasındaki üç aylık dönemde toplanmıştır.

\section{Veri Toplama Aracı}

Araştırmanın amacına uygun olarak hazırlanmış ankette araştırma değişkenleriyle ilgili ölçekler ve cevaplayıcıların demografik özellikleri ile ilgili sorular yer almaktadır. İlgili yazın taraması sonucunda ölçekte yer alan engellilerin algıladıkları turizm kısıtlarını ölçmeye yönelik 8 ifade derlenmiştir (Smith 1987; Darcy 2002; Israeli 2002; McKercher vd. 2003; Shaw ve Coles 2004; Yau vd. 2004; Daniels vd. 2005; Lee vd. 2011). Engellilerin öğrenilmiş çaresizlik düzeylerini ölçmeye yönelik 5 ifade Lee ve arkadaşlarının (2011) çalışmasından alınmıştır. Engellilerin turist olma motivasyonu gücü ise Carrol ve Alexandris (1997) ve Alexandris ve arkadaşlarının (2011) çalışmasında kullanmış olduğu ölçekteki 5 ifadeden oluşmaktadır. Engellilerin turist olma niyeti ise ilgili yazından derlenen 3 ifade ile ölçülmüştür (Bigne vd. 2001; Sarıkaya vd. 2004). Ölçüm aracında 5 maddeli Likert tipi ölçek (1: kesinlikle katılmıyorum, 5: kesinlikle katılıyorum) kullanılmiştır. Anket, konusunda uzman akademisyenler ve engelli temsilcileri tarafından gözden geçirilmiş ve ifadelerin anlaşılırlığ açısından gerekli düzeltmeler yapılmıştır.

\section{Veri Analizi}

Verilerin analizi ve tanımlayıcı istatistikleri için SPSS for Windows 19.0 paket programı kullanılmıştır. Doğrulayıcı faktör analizi ve hipotezlerin test edilmesi için oluşturulan yapısal eşitlik modeli ise LISREL 8.0 ile analiz edilmiştir. Veri setindeki eksik verilerin yerine serilerin ortalamaları yerleştirilmiştir. Ayrıca, verilerin normal dağılıma uygunluğunu test etmek için Kolmogorov Smirnov Testi kullanılmış, her bir değişken için test değerleri ve anlamlılık değerlerinde bir sorun olmadığ görülmüştür. Bunun yanında veri setinde uç/aykırı değerler olup olmadığı incelenerek uç/aykırı değerlerin bulunmadığı gözlenmiş ve analizler 239 kişi üzerinde gerçekleştirilmiştir. 


\section{Ölçeklerin Geçerliliği ve Güvenilirliği}

Veri analiz sürecinin ilk aşamasında ölçeklerin saflaştırılması, geçerliliği ve güvenilirliği için analizler yapılmıştır. Araştırmada ölçeklerin güvenirliğini göstermek için ilk olarak iç tutarlılık yöntemi kullanılmıştır. SPSS programı yardımıyla yapılan güvenilirlik analizi sürecinde ölçeklerin iç tutarlılığını düşüren ve ifade-boyut (item to total) korelâsyonu ve/veya faktör yükleri düşük olan ifadeler, ölçeklerden çıkarılmıştır. Bunun nedeni, düşük faktör yüküne ve düşük ifade-boyut (item-to-total) korelâsyonuna sahip ifadelerin, ilgili kavramı ölçme olasılığının oldukça düşük olmasıdır (Özdamar 2004). Buna göre, turizm kısıtları ölçeğinden 4 madde, turist olma niyeti ölçeğinden ise 1 madde çıkarılmıştır. Her bir ölçeğin Cronbach's Alfa değerleri yazında tavsiye edilen değerleri $(0,70$ ve üzeri) tatmin edilir derecede yakalamıştır (Tablo 1) ve ölçeklerin güvenilir olduğunu göstermektedir (Nunnally 1978). Çalışmada kullanılan dört ölçeğin yapı geçerliliğini incelemek amacıyla her bir ölçek için ayrı ayrı olmak üzere açıklayıcı faktör analizi gerçekleştirilmiştir. Faktör analizi sonucunda her bir ölçeğin tek faktörlü yapıya sahip olduğu gözlenmiştir. Ölçekler, faktör yükleri, Cronbach's Alfa değerleri ve yapı geçerliliğinin göstergesi olan tek faktörlü yapının toplam varyansı açıklama oranı Tablo 1'de verilmiştir.

\section{Ölçme Modeli}

İkinci aşamada ölçme modelinin test edilmesi için doğrulayıcı faktör analizi yapılmıştır. Ölçme modeline ilişkin doğrulayıcı faktör analizi sonuçları Tablo 2'de verilmiştir. Ölçme modeli, LISREL 8,80'in ürettiği kovaryans çıktısı üzerinden en yüksek olabilirlik kestirim yöntemi kullanılarak gerçekleştirilen doğrulayıcı faktör analizi ile belirlenmiştir. Analiz sonuçları incelendiğinde, $\chi 2$ 'nin serbestlik derecesi bölümünden elde edilen oranın 3'ün altında olduğu, RMSEA değerinin 0,036 olduğu, GFI, AGFI, NFI, değerlerinin 0,90'ın üzerinde olduğu ve NNFI, CFI ve IFI değerlerinin 0,90'1n üzerinde olduğu görülmüştür. Uyum indekslerini incelemek üzere, modele ait uyum indekslerine genel olarak bakıldığında başta $\chi 2$ /sd oranı olmak üzere tümünün kabul değeri koşullarını karşıladığ1 görülmektedir (Chau 1997; Hair vd. 2006; Şimşek 2007). Bunun anlamı önerilen ölçme modelinin veriye uygun olduğudur. Fornell ve Larcker (1981) yapısal eşitlik modellemede üç tür güvenilirlikten bahseder. Bunlar; madde güvenilirliği, yapı güvenilirliği ve açıklanan ortalama varyanstır. Bu değerlerin hepsinin 0,50'den büyük olması gerekmektedir. Tablo 2'de görüldüğü gibi ölçeklerdeki yapı güvenilirliği değerleri ve ortalama açıklanan varyans değerleri 0,50'den büyüktür. Ayrıca madde güvenilirliğinin bir göstergesi olan gözlenen

Tablo 1. Ölçekler, Faktör Yükleri ve Açıklanan Toplam Varyans

\begin{tabular}{|c|c|c|c|}
\hline Ölçekler & Ölçek maddeleri & Faktör yükleri & $\begin{array}{l}\text { Toplam Varyansı } \\
\text { Açıklama Oranı }\end{array}$ \\
\hline \multirow[t]{4}{*}{$\begin{array}{l}\text { Turizm kısıtları } \\
\alpha=0,79\end{array}$} & $\begin{array}{l}\text { Turizm faaliyetlerine katılırken başkalarını rahatsız ve huzursuz } \\
\text { etmekten korkuyorum. }\end{array}$ &, 708 & \\
\hline & $\begin{array}{l}\text { Turizm faaliyetlerine katılırken diğer insanların önyargılarını } \\
\text { hissetmek beni rahatsız eder. }\end{array}$ & ,839 & 0,62 \\
\hline & Turizm faaliyetlerine katılırken diğer insanlarla uyum sağlayamam. & ,837 & \\
\hline & Turizm bölgelerinde engellilere yönelik düzenlemeler ve imkânlar yetersiz. &, 746 & \\
\hline \multirow{6}{*}{$\begin{array}{l}\text { Turist olma } \\
\text { motivasyonu gücü } \\
\alpha=0,90\end{array}$} & Tatile çıkmam mümkün olmadığında pişmanlık duyarım. & ,857 & \\
\hline & Turizm faaliyetlerine katılma konusunda şartlarım uygun olmasa da & & \\
\hline & katılmayı denerim. & ,823 & 0,73 \\
\hline & Turizm faaliyetlerine katılmak benim için hayati öneme sahiptir. & ,858 & \\
\hline & Turizm faaliyetlerine katılmak için elimden gelen tüm çabayı sarf ederim. & ,821 & \\
\hline & Turizm faaliyetlerine katılmayı çok istiyorum. & ,899 & \\
\hline \multirow{5}{*}{$\begin{array}{l}\text { Öğrenilmiş } \\
\text { çaresizlik } \\
\alpha=0,86\end{array}$} & Turist olmak beni mutlu edecek bir şey değildir. & ,753 & \\
\hline & Turist olmak bana zorluk yaşatır ve sadece acı verir. & ,785 & \\
\hline & Turist olmak beni kasvetli bir ruh haline sokar. & ,851 & 0,65 \\
\hline & Turist olmak benim için uygun değildir. & ,830 & \\
\hline & Huzurlu ve rahat bir turizm ortamı benim için var olamaz. & ,800 & \\
\hline \multirow{2}{*}{$\begin{array}{l}\text { Turist olma niyeti } \\
\alpha=0,77\end{array}$} & Turist olmak için bir şans yakalarsam hemen değerlendireceğim. & ,902 & \\
\hline & Seyahat etme becerimi iyileştirmek için her şeyi yapacağım. & ,902 & 0,81 \\
\hline
\end{tabular}


Beykan Çizel - Rabia Bato Çizel

Tablo 2. Ölçme Modeline İlişkin Doğrulayıcı Faktör Analizi ve Güvenilirlik Değerlendirmelerinin Sonuçları

\begin{tabular}{|c|c|c|c|c|}
\hline & $\begin{array}{r}\text { Standardize } \\
\text { parametre } \\
\text { değerleri }\end{array}$ & $T$ - değerleri & $\begin{array}{r}\text { Yapı } \\
\text { güvenilirliği }\end{array}$ & $\begin{array}{r}\text { Ortalama } \\
\text { açıklanan } \\
\text { varyans }\end{array}$ \\
\hline Turizm Kısıtları & & & 0,80 & 0,50 \\
\hline Eng1 & 0,56 & 8,68 & & \\
\hline Eng2 & 0,80 & 13,29 & & \\
\hline Eng3 & 0,81 & 13,44 & & \\
\hline Eng4 & 0,62 & 9,75 & & \\
\hline Turizm Motivasyonu Gücü & & & 0,91 & 0,66 \\
\hline Mot1 & 0,83 & 15,42 & & \\
\hline Mot2 & 0,77 & 13,74 & & \\
\hline Mot3 & 0,80 & 14,53 & & \\
\hline Mot4 & 0,76 & 13,40 & & \\
\hline Mot5 & 0,89 & 17,17 & & \\
\hline Öğrenilmiş Çaresizlik & & & 0,86 & 0,56 \\
\hline Çar1 & 0,67 & 11,14 & & \\
\hline Çar2 & 0,74 & 12,72 & & \\
\hline Çar3 & 0,83 & 14,86 & & \\
\hline Çar4 & 0,78 & 13,59 & & \\
\hline Çar5 & 0,72 & 12,18 & & \\
\hline Turist Olma Niyeti & & & 0,79 & 0,65 \\
\hline Niy1 & 0,71 & 11,09 & & \\
\hline Niy2 & 0,89 & 14,11 & & \\
\hline
\end{tabular}

Ölçme Modelinin Uyum indeksleri

$\chi 2=128.89, \mathrm{sd}=98 \chi 2 / \mathrm{sd}=1,31, \mathrm{RMSEA}=0.036, \mathrm{GFI}=0.94, \mathrm{AGFI}=091, \mathrm{NFI}=0.96, \mathrm{NNFI}=0.99, \mathrm{CFI}=0.94$, ve IFI= 0.99

değişkenler ile ilgili yapılar arasındaki standardize parametre değerlerinin hepsi 0,50'den büyüktür. Sonuçlar ölçekler için ayrı ayrı güvenilirlik kriterinin sağlandığını gösterir. Madde güvenilirliği, yapı güvenilirliği ve açıklanan ortalama varyans değerlerin hepsinin aynı zamanda 0,50'den büyük olması yakınsama geçerliliğinin de sağlandığını göstermektedir (Fornel ve Larcker 1981). Yapı geçerliliğinin bir diğer göstergesi olan ayrışma geçerliliğini göstermek için ise yine Fornel ve Larcker'in (1981) önerdiği yöntem kullanılmıştır. Yazarlara göre ayrışma geçerliliğini göstermek, her bir yapının ortalama açıklanan varyansı, değişkenler arasındaki ikili korelâsyonların karesinden büyük olması durumunda mümkün olur. Tablo 3'te görüldüğü gibi modeldeki tüm değişkenler arasındaki korelâsyonların karesi ortalama açıklanan varyans değerlerinden küçüktür ve bu ölçeklerin ayrışma geçerliliğine sahip olduğunu gösterir.

\section{ARAȘTIRMANIN BULGULARI}

Engellilerle ilgili demografik bulgular Tablo 4'te verilmiştir. Engel türleri incelendiğinde, araştırmaya katılan engellilerin $\% 33,05$ 'i görme, \%32,22'si işitme/duyma ve \%34,73'ü ise bedensel engellidir. Engel sebebi incelendiğinde ise büyük bölümünün doğuştan-genetik $(46,86)$ olduğu görülmektedir. Yaşlarına bakıldı ğında engellilerin \%51,46'sının orta yaş grubunda yer aldığı belirlenmiştir. Erkek engellilerin oranı $(\% 63,18)$ neredeyse kadınların oranının $(\% 36,82)$ iki katıdır. Eğitim durumlarına bakıldığında, engellilerin \%10,88' inin hiç okula gitmemiş, \% 39,33'ünün ise ilkokul mezunu olduğu görülmektedir. Lise ve dengi okulu bitirmiş olan engellilerin oran $\% 32,64$, önlisans mezunu olanlar \%11,3 ve lisans mezunu olanlar ise yalnızca $\% 5,86$ 'dır. Eğitim durumları ile ilgili bir değerlendirme yapmak gerekirse, engellilerin lise sonrasında eğitim imkânlarından istenilen düzeyde yararlanamadığını söylemek yanlış olmaz. Engellilerin 
Tablo 3. Değişkenler Arasındaki Korelasyon Değerleri ve Toplam Açılanan Varyans

\begin{tabular}{|c|c|c|c|c|}
\hline & Turizm kısıtları & Turizm Motivasyonu gücü & Öğrenilmiş Çaresizlik & Turist olma Niyeti \\
\hline Turizm kısıtları & $0,50 a$ & & & \\
\hline Turist olma motivasyonu gücü & $-0,191 b$ & $0,66 a$ & & \\
\hline Öğrenilmiş çaresizlik & $0,375 b$ & $-0,372 b$ & $0,56 a$ & \\
\hline Turist olma niyeti & $-0,083 b$ & $0,556 \mathrm{~b}$ & $-0,388 b$ & $0,65 a$ \\
\hline
\end{tabular}

medeni durumu incelendiğinde ise yarıdan fazlasının $(\% 55,23)$ bekâr olduğu göze çarpmaktadır. Yine araştırmaya katılan engellilerin \%67,36'sı çalışma hayatının dışında kalmaktadır. Aylık kişisel gelirleri incelendiğinde \%43,1'i 1000 TL'nin altında kazandıklarını beyan etmişlerdir. Bu soruya verilen cevaplar incelendiğinde engellilerin \%30,69'unun hiç geliri olmadığı göze çarpmaktadır. Aylık hane gelirleri ile ilgili değerlendirme yapıldığında ise yine \%34,31'i hane gelirinin aylik 1000 TL'nin altında olduğunu, \%33,47'si ise 1000 TL ile 2000 TL arasında gelire sahip olduklarını ifade etmektedirler. Bu iki sorunun ortaya koyduğu durum özetle engellilerin zor şartlar altında yaşamlarını sürdürmek zorunda olduklarıdır. Gelir darlığı elbetteki engellilerin turizm amaçlı hareketliliğini engelleyen önemli bir kısıt olacaktır. Engellilerin \%51,05'i engel türüne uygun sivil toplum örgütlerine üyedirler. Bu durum engellilerin toplum hayatına sivil toplum örgütleri vasıtasıyla tutunmaya çalıştıklarını göstermektedir.

\section{Yapısal Model (Hipotezlerin Test Edilmesi)}

Ölçme modelinin doğrulanması ile araştırmanın hipotezlerinin yapısal model ile test edilmesinde bir sakınca olmadı̆̆ı anlaşılmıştır. Çalışmada, öncelikle engellilerin algıladıkları turizm kısıtları ve turist olma niyeti ilişkisinde öğrenilmiş çaresizlik ve turist olma motivasyonu gücünün aracı etkisi test edilmiştir. İkinci aşamada ise değişkenler arası ilişkiler oluşturulan hipotezler doğrultusunda incelenmiştir. Modelde açıklanmaya çalışılan ilişki örüntüleri Şekil 1'de görülmektedir. Modelde ifade edilen her yol aynı zamanda bir hipotez olarak görülmelidir. Araştırmanın amaçlarından biri olan modeldeki aracılık etkilerini test etmek için, kısmen aracı bir model ve bu modelin alt modelleri olarak adlandırılabilecek olan iç içe geçmiş yapisal modelleri (nested models) test etme stratejisi izlenmiştir (Anderson ve Gerbing 1988). Şekil 1'de yer alan temel model (TM) hipotezlerle ifade edilen tüm doğrudan ve dolaylı ilişkileri yansıtmaktadır. Test edilen alternatif modelde (AM) ise aracilık etkisi testi için temel modelden turizm kısıtlarından turist olma niyetine giden doğrudan yol kaldırılmıştır. Bu modelde iki aracı değişkenin (öğrenilmiş çaresizlik ve turist olma motivasyonu gücü), tümüyle aracı etkisi aynı anda test edilmiştir. Modelde eksik olan bu yol aracılık etkilerinin tümüyle söz konusu değişkenler ile sağlandığı anlamına gelmektedir. Tablo 5'te verilen uyum iyiliği istatistikleri çok kötüleşmese de yapılan ki-kare farklılık testi bu farkın anlamlı olduğunu göstermektedir. Bu sonuç bize modelden silinen yolun model için önemli bir ilişki olduğunu gösterir ve sözkonusu modelin reddedilmesi gerekir. Dolayısıyla temel model kabul edilmiştir. Söz konusu değişkenler (öğrenilmiş çaresizlik ve turist olma motivasyonu gücü) engellilerin turizm kısıtları ve turist olma niyeti ilişkisinde kısmen aracı değişken oldukları belirlenmiştir (hipotez 4 ve hipotez 8 ). Modelin son haline iliş̧in standardize edilmiş çözüm değerleri Şekil 1'de verilmiştir. Tablo 5. Uyum İndeksleri (Teorik Model ve Alternatif Model)

Tablo 5'te kabul edilen teorik yapısal modele ilişkin uyum indekslerinin, $\chi 2=128,89, \chi 2 / \mathrm{sd}=1,31$, RMSEA=0,036, GFI=0,94, AGFI=0,91, NFI=0,96, NNFI=0,99, CFI=0,99, ve IFI= 0,99 olduğu gözlenmektedir. Analiz sonuçları incelendiğinde, $\chi 2$ 'nin serbestlik derecesine bölünmesi ile elde edilen oranının 3'ün altında olduğu, RMSEA değerinin 0,0036 olduğu, GFI, AGFI, NFI değerlerinin 0,90'in üzerinde olduğu ve yine NNFI CFI ve IFI değerlerinin 0,90 'ın üzerinde olduğu görülmüştür. Uyum indekslerini incelemek üzere, modele ait uyum indekslerine genel olarak bakıldığında, başt $\chi 2 /$ sd oranı olmak üzere tümünün uyum indeksi kabul değeri koşullarını karşıladığı görülmektedir (Hair 
Tablo 4. Engelliler ile İlgili Demografik Bulgular (N=239)

\begin{tabular}{|c|c|c|c|}
\hline & & Sayı & Yüzde \\
\hline \multirow[t]{2}{*}{ Yerleşim Yeri } & Ankara & 76 & 31,8 \\
\hline & İzmir & 82 & 34,31 \\
\hline \multirow{4}{*}{ Engel Türü } & İstanbul & 81 & 33,89 \\
\hline & Görme & 79 & 33,05 \\
\hline & İşitme/Duyma & 77 & 32,22 \\
\hline & Bedensel & 83 & 34,73 \\
\hline \multirow[t]{6}{*}{ Engel Sebebi } & Çocukluk hastalığı & 61 & 25,52 \\
\hline & Yanlış tedavi & 20 & 8,37 \\
\hline & Doğuştan-genetik & 112 & 46,86 \\
\hline & Yaşlılık & 3 & 1,26 \\
\hline & Kaza (iş, vb.) & 31 & 12,97 \\
\hline & Diğer & 12 & 5,02 \\
\hline \multirow[t]{5}{*}{ Yaş } & $15-24$ & 41 & 17,15 \\
\hline & $25-34$ & 63 & 26,36 \\
\hline & $35-44$ & 60 & 25,1 \\
\hline & $45-54$ & 53 & 22,18 \\
\hline & $55+$ & 22 & 9,21 \\
\hline \multirow[t]{2}{*}{ Cinsiyet } & Kadın & 88 & 36,82 \\
\hline & Erkek & 151 & 63,18 \\
\hline \multirow{5}{*}{ Eğitim Durumu } & Hiç okula gitmemiş & 26 & 10,88 \\
\hline & İlköğretim & 94 & 39,33 \\
\hline & Lise ve dengi & 78 & 32,64 \\
\hline & Önlisans & 27 & 11,3 \\
\hline & Lisans & 14 & 5,86 \\
\hline \multirow[t]{3}{*}{ Medeni Durum } & Evli & 132 & 37,66 \\
\hline & Bekâr & 17 & 55,23 \\
\hline & Dul & 90 & 7,11 \\
\hline \multirow[t]{2}{*}{ Çalışma Durumu } & Evet & 78 & 32,64 \\
\hline & Hayır & 161 & 67,36 \\
\hline \multirow[t]{5}{*}{ Aylık Kişisel Gelir } & 1.000TL'den az & 103 & 43,1 \\
\hline & 1.001TL- $2.000 T L$ arası & 31 & 12,97 \\
\hline & 2.001TL- 3.000 TL arası & 1 & 0,42 \\
\hline & Cevap Yok & 30 & 12,55 \\
\hline & Geliri yok & 74 & 30,96 \\
\hline \multirow[t]{5}{*}{ Aylık Hane Geliri } & 1.000TL'den az & 82 & 34,31 \\
\hline & 1.001TL- 2.000TL arası & 80 & 33,47 \\
\hline & 2.001TL- 3.000 TL arası & 20 & 8,37 \\
\hline & 3.001TL- 4.000TL arası & 1 & 0,42 \\
\hline & Cevap Yok & 56 & 23,43 \\
\hline \multirow[t]{2}{*}{ Sivil Toplum Örgütü Üyeliği } & Evet & 122 & 51,05 \\
\hline & Hayır & 117 & 48,95 \\
\hline
\end{tabular}

vd. 2006; Şimşek 2007). Dolayısıyla bu çalışmada temel modelin uygun olduğu görülmüştür.

Çalışmanın ikinci aşamasında, modelin değişkenleri arasındaki ilişkiler oluşturulan hipotezler doğrultusunda incelenmiştir. "Engellilerin algıladikları turizm kısıtları turist olma niyetini negatif yönde etkiler" şeklinde ifade edilen birinci hipotez doğrulanmaktadır. Standardize edilmiş yol katsayısı $\beta=-0,17$ olarak bulunmuştur. Bu iki değişken arasındaki ilişkinin düşük düzeyde ve anlamlı olduğu anlaşılmaktadır $(\beta=-0,17 ; \mathrm{t}=-2,36 ; \mathrm{p}<0,05)$. Bu değer, engellilerin algıladıkları turizm kısıtları düzeyindeki bir puanlık artışın turist olma niyetinde 0,17 puanlık azalışa neden olacağını ifade et- 


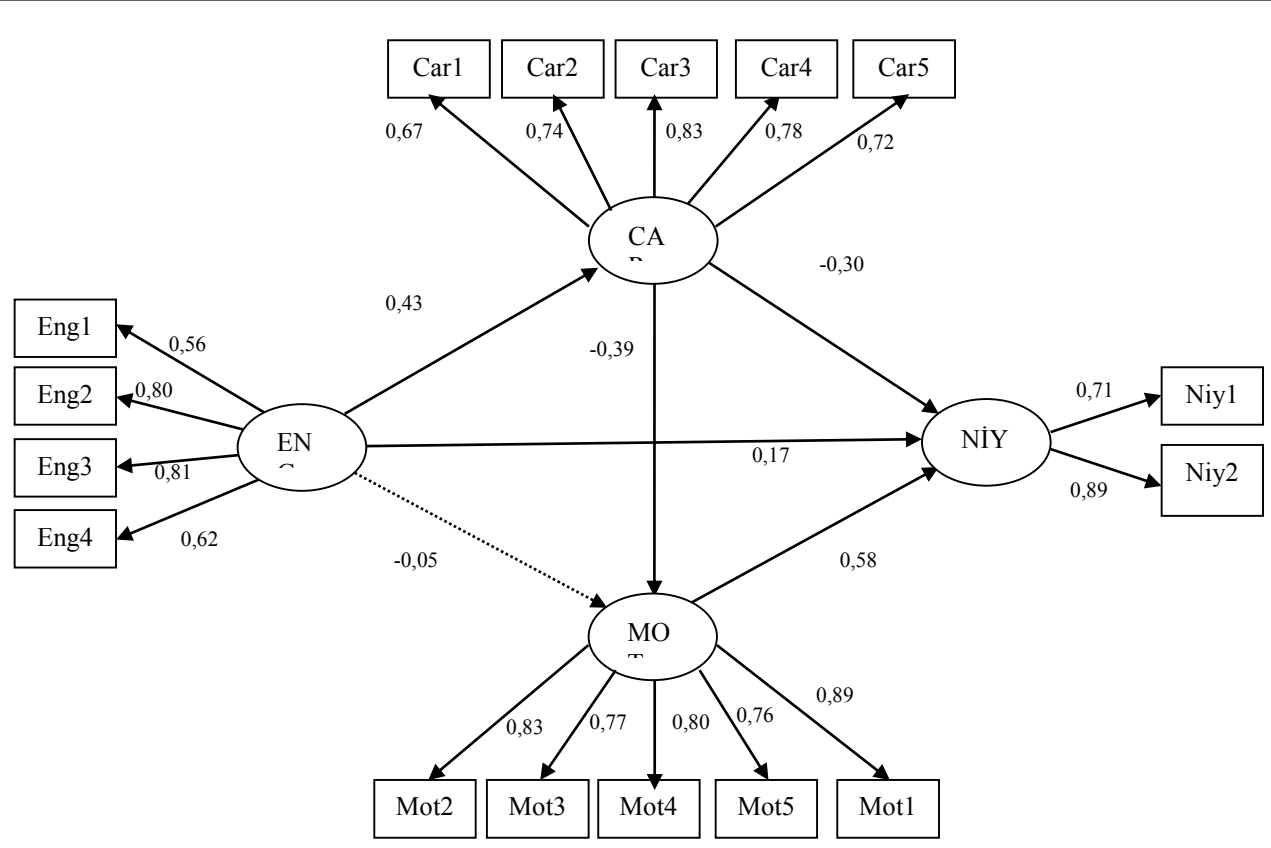

Şekil 1. Yapısal Model

mektedir. Araştırmanın "engellilerin algıladıkları turizm kısıtları, turist olma motivasyonu gücünü negatif yönde etkiler" şeklinde ifade edilen ikinci hipotezi ise doğrulanmamıştır $(\beta=-0,05 ; \mathrm{t}=-0,58$; $p>0,05)$. Dolayısıyla bu iki değişken arasında ilişkinin olmadığ 1 anlaşılmaktadır. Araştırmada "engellilerin turist olma motivasyonu gücü, turist olma

Tablo 5. Uyum İndeksleri (Teorik Model ve Alternatif Model)

\begin{tabular}{lrr}
\hline Models & $T M$ & AM \\
\hline Ki-kare & 128,89 & 133,88 \\
\hline df & 98 & 99 \\
\hline Ki-kare/sd & 1,31 & 1,35 \\
\hline GFI & 0,94 & 0,93 \\
\hline AGFI & 0,91 & 0,91 \\
\hline NFI & 0,96 & 0,96 \\
\hline NNFI & 0,99 & 0,99 \\
\hline CFI & 0,99 & 0,99 \\
\hline IFI & 0,99 & 0,99 \\
\hline ECVI & 0,86 & 0,87 \\
\hline RMSEA & 0,036 & 0,038 \\
\hline SRMR & 0,042 & 0,045 \\
\hline Critical N & 244,39 & 236,31 \\
\hline
\end{tabular}

niyetini pozitif yönde etkiler" şeklinde ifade edilen üçüncü hipotezi de kabul edilmiştir $(\beta=0,58 ; \mathrm{t}=$ 6,75; $p<0,05)$. Modeldeki en kuvvetli ilişkinin bu iki değişken arasında olduğu görülmektedir.

“Engellilerin algıladıkları turizm kısıtları, turizm faaliyetlerine katılmalarına ilişkin öğrenilmiş çaresizlik düzeyini pozitif yönde etkiler" şeklinde ifade edilen beşinci hipotezi ve "engellilerin turizm faaliyetlerine katılmalarına ilişkin öğrenilmiş çaresizlik düzeyi, turist olma motivasyonu gücünü negatif yönde etkiler" şeklinde ifade edilen altıncı hipotezi kabul edilmiştir. Standardize edilmiş yol katsayıları ve $t$ değerleri ise sırasıyla; $\beta=0,43 ; t=$ 5,$40 ; p<0,05 ; \beta=-0,39 ; t=-4,68 ; p<0,05$ olarak hesaplanmıştır. Son olarak "engellilerin öğrenilmiş çaresizlikleri, turist olma niyetini negatif yönde etkiler" şeklindeki yedinci hipotezi de kabul edilmiştir ( $\beta$ $=-0,30 ; \mathrm{t}=-3,67 ; \mathrm{p}<0,05)$. Yapısal eşitlik modeli sonuçları Tablo 6'da görülmektedir.

\section{SONUÇ VE TARTIŞMA}

Araştırma bulguları, engellilerin turist olma niyeti ile turizm kısıtları arasında ters yönde zayıf bir ilişki olduğunu göstermektedir. Turizm kısıtları turist olma niyetindeki değişimin ancak \%17'sini açıklamaktadır. Bu durum yazındaki diğer araştır- 
Tablo 6. Yapısal Eşitlik Modeli Sonuçları

\begin{tabular}{lrrr}
\hline Değişkenler arası ilişkiler & & & \\
\hline & $\beta$ & $t$ & Hipotez \\
\hline Turizm kısıtları $\rightarrow$ Turist olma niyeti & $-0,17$ & $-2,34$ & Kabul \\
\hline Turizm kısıtları $\rightarrow$ Turist olma motivasyonu gücü & $-0,05$ & $-0,58$ & Red \\
\hline Turist olma motivasyonu gücü $\rightarrow$ Turist olma niyeti & 0,58 & 6,75 & Kabul \\
\hline Turizm kısıtları $\rightarrow$ Engellilerin öğrenilmiş çaresizlikleri & 0,43 & 5,40 & Kabul \\
\hline Engellilerin öğrenilmiş çaresizlikleri $\rightarrow$ Turist olma motivasyonu gücü & $-0,39$ & $-4,68$ & Kabul \\
\hline Engellilerin öğrenilmiş çaresizlikleri $\rightarrow$ Turist olma niyeti & $-0,30$ & $-3,67$ & Kabul \\
\hline
\end{tabular}

ma sonuçları ile tutarlıdır (Smith 1987; Israeli 2002; Lee vd. 2011). Araştırmaya katılan engelliler turist olma kararı verirken turizm kısıtlarını göz ardı etmemekte, ancak bu onların turist olma niyetini çok yüksek oranda negatif yönde etkilememektedir. Araştırma modeli ilk kez turist olma niyeti ile engeller arasındaki ilişkinin anlaşılmasında iki kısmi aracı değişkenin (turist olma motivasyonu gücü ve turizm faaliyetlerine katılmaya ilişkin öğrenilmiş çaresizlikleri) önemini ortaya koymaktadır. Seyahat motivasyonu, bireyleri seyahate iten motifler ve ihtiyaçlar olarak tanımlanmaktadır (Pearce 2005). Bu çalışmada kullanılan motivasyon gücü ise bireylerin motivasyon yoğunluğunu ölçmeye yöneliktir. Ayrıca çalışmada kullanılan model bireylerin turist olma niyetini etkileyen motivasyon gücü üzerinde öğrenilmiş çaresizlik algısının etkisini de göstermektedir. Diğer bir ifadeyle bu çalışma engellilerin turizm kisıtları ve turist olma niyeti ilişkisinde sözü edilen iki psikolojik değişkenin ilk kez tek bir model içerisinde incelenmesini sağlamiştır.

Araştırma modelinde turizm kısıtları ile turist olma motivasyonu gücü arasında daha önce yapılan araştırma (Carroll ve Alexandris 1997; Alexandris vd. 2002; Alexandris vd. 2011) sonuçlarından farklı olarak doğrudan negatif bir ilişki bulunamamıştır. Yapısal modelin değişkenleri arasındaki ilişkilere bakıldığında, engellilerin turizm kısıtları, turist olma motivasyonu gücünü etkilemese de turizm faaliyetlerine katılma yönündeki öğrenilmiş çaresizlik algısını arttırmaktadır. Artan ögrenilmiş çaresizlik algisı ise engellilerin hem turist olma niyetini doğrudan düşürmekte hem de turist olma motivasyonu gücünü ciddi şekilde azaltarak dolaylı olarak turist olma niyetini negatif yönde etkilemektedir. Araştırma sonuçlarına göre turist olma motivasyo- nu gücü turist olma niyetindeki değişimin $\% 58$ 'ini açıklamaktadır. Diğer bir ifadeyle, engelliler karşılaştıkları seyahat engelleri nedeniyle kendilerini çaresiz hissetmekte ve bu durum dolaylı olarak motivasyonlarına yansımaktadır. Araştırma modelinde bu yönde ortaya konan görgül kanit, ilgili yazın için yeni ve önemli bir katkıdır. Daha önce yapılan çalışmalarda (Lee vd. 2011;Alexandris vd. 2011) yukarıda sözü edilen değişkenler tek tek modele sokulmuş ve seyahat engelleri ve turist olma motivasyonu ilişkisindeki aracılık rolleri incelenmiştir. Ancak öğrenilmiş çaresizlik ile motivasyon gücü arasındaki ilişkiler göz ardı edilmiştir. Bu çalışmada kullanılan modelde görüleceği üzere seyahat engelleri ile engellilerin motivasyon gücü arasındaki ilişki doğrudan olmasa da öğrenilmiş çaresizlik üzerinden dolaylıdır.

Araştırma sonuçları, engellilerin turizm faaliyetlerine katılma kararı verirken algıladıkları engellerin etkisinin doğrudan az olsa da dolaylı olduğu fikrini desteklemektedir (Lee vd. 2011; Alexandris vd. 2011). Ancak, bu çalışmada kullanılan araştırma modeli ve yapilan analizler, engellilerin turist olma niyeti ile turizm kısıtları ilişkisinin açıklanmasında, engellilerin turist olma motivasyonu gücü ve turizm faaliyetlerine katılma yönündeki öğrenilmiş çaresizlik algısınının kısmen aracı değişkenlik yaparak yardımcı olduğunu göstermektedir. Bu bulgulardan yola çıkarak, engelli bireylerin turizm kısıtlarının doğrudan turist olma niyetini düşüren önemli etkisinin olmadığ 1 ancak engellilerin turizm faaliyetlerine katılma yönündeki öğrenilmiş çaresizliklerini arttırarak ve turist olma motivasyonu gücünü düşürerek turizme katılım niyetini dolaylı olarak etkilediği söylenebilir.

Turist olma niyeti ile turizm kısıtları arasındaki doğrudan ilişkiyi ifade eden yolun modelden çı- 
karılamamış olması (alternatif modelin kabul edilememesi) söz konusu iki değişken arasındaki ilişkinin tümüyle aracı değişkenlerle sağlanamadığını göstermektedir. Bu çalışmanın bir diğer önemli katkısı ise bu noktadadır. Araştırma bulguları engellilerin seyahat engelleri ile seyahat niyeti ilişkisinde öngörülen psikolojik değişkenlerin birlikte ilişkinin gücünü arttırdığını ortaya koymaktadır. Bunu şu şekilde yorumlayabiliriz: Engelliler seyahat niyeti oluşum sürecinde seyahat engellerine yönelik olumsuzluklardan doğrudan etkilenmektedirler. Bunun yanında, tecrübe ettikleri seyahat engelleri engellilerin psikolojileri üzerinde etkili olmakta ve bu durum bir sonraki seyahat niyetini önemli oranda düşürmektedir. Bu bulgular, seyahat engelleri ile baş etmeye çalışan engellilerin başarısız çabalarının, psikolojileri (motivasyon gücünü ve öğrenilmiş çaresizlik) üzerinde tahribat yarattığını ve dolaylı olarak seyahat niyetini olumsuz etkilediğini ortaya koymaktadır.

Yapılan görgül araştırma sonuçlarına dayanan bu saptama doğrultusunda bu alanda çalışmak isteyen araştırmacılar nitel araştırma yöntemleri kullanarak, engellilerin seyahat karar verme sürecinde seyahat engellerinin onların psikolojileri üzerinde nasıl etkili olduğunu ve tekrar seyahat etme niyetinin artırılmasında nasıl bir yol izlenmesi gerektiğini inceleyebilirler. Bu araştırma konusu ülkemizde hemen her alanda ciddi engeller ile karşılaşan ve evden dışarıya çıkmak istemeyen engellilerin turizm bağlamında aktif hale getirilmesinde önemli bir çaba olacaktır.

Sonuç olarak, engellilerin turizme katılım niyetini azaltan turizm kısıtlarının neler olduğunun saptanması ve ortadan kaldırılması, onların turist olma niyetinin artmasında doğrudan ve dolay11 olarak etkilidir. Engelliler turist olma kararı verirken geçmiş turizm tecrübelerinde karşılaştıklar1 engelleri içselleştirmekte ve bu durum onların psikolojilerini etkilemektedir. Bu nedenle, seyahat engellerinin onların psikolojileri üzerinde yaratmış olduğu olumsuzluklar göz ardı edilmemelidir. Aksi takdirde, engellilerin turizm kisitları ortadan kaldırılsa bile turist olma niyetleri artmayacaktır. $\mathrm{Bu}$ nedenle, engelli bireylerin turizm kısitlarından etkilenme süreci, bu çalışmada önerilen ve önemli olduğu gösterilen motivasyon gücü ve öğrenilmiş çaresizlik gibi psikolojik değişkenlerle birlikte ilişkilendirilerek değerlendirilmelidir. Diğer bir deyişle engelli turist davranışının daha iyi analiz edilebilmesi için psikolojik faktörlerin dikkate alınması önerilmektedir.

Yazında motivasyon gücünün önemli bilişsel, duyuşsal ve davranışsal sonuçları olduğu vurgulanmaktadır. Bu çalışmada, davranışsal sonuçları bağlamında davranışsal niyet incelenmiştir. Gelecekte yapılacak araştırmalarda motivasyonun gücünün bilişsel sonuçları (bilgi toplama, hatıra vb.) ve duyuşsal sonuçları (ruh hali, önem, tatmin, kayg1 vb.) ile turizm kısıtları arasındaki ilişkiler incelenebilir. Özellikle engellilerin seyahat öncesi, esnası ve sonrasında turist davranışının analiz edilmesi oldukça önemlidir.

Çalışma kapsamında Türkiye'nin üç büyük kentinde yaşayan ve ismi geçen sivil toplum örgütlerine kayıtlı engelliler araştırmaya dâhil edilmiştir. Sivil toplum örgütlerine kayıtlı olmayan engellilere ulaşılamamış olması araştırmanın bir diğer kısıtıdır. Ayrıca, örneklemin 239 kişi olması bu araştırmanın bir diğer kısıtı olarak değerlendirilebilir.

\section{KAYNAKÇA}

Abeyraine, R. I. (1995). Proposals and Guide-Lines for The Carriage of Elderly and Disabled Persons By Air, Journal of Travel Research, 33 (3): 52-59.

Ajzen, I. (1991). The Theory of Planned Behavior, Organizational Behavior and Human Decision Processes, 50: 179-211.

Alegre, J., Mateo, S. ve Pou, L. (2010). An Analysis of Households' Appraisal of Their Budget Constraints for Potential Participation in Tourism, Tourism Management, 31: 45-56.

Alexandris, K. ve Carroll, B. (1997). An Analysis of Leisure Constraints Based on Different Recreational Sport Participation Levels: Results From a Study in Greece, Leisure Sciences, 19: 1-15.

Alexandris, K., Tsorbatzoudis, C. ve Grouios, G. (2002). Perceived Constraints on Recreational Participation: Investigating Their Relationship with Intrinsic Motivation, Extrinsic Motivation and Amotivation, Journal of Leisure Research, 34: 233-252.

Alexandris, K., Kouthouris, C. ve Girgolas, G. (2007). Investigating The Relationships among Motivation, Negotiation, and Alpine Skiing Participation, Journal of Leisure Research, 39 (4): 648-667.

Alexandris, K., Funk, D. C. ve Pritchard, M. (2011). The Impact of Constraints on Motivation, Activity Attachment and Skier Intentions to Continue, Journal of Leisure Research, 43 (1): 56-79.

Anderson, J. C. ve Gerbing, D. W. (1988). Structural Equation Modeling in Practice: A Review and Recommended TwoStep Approach, Psychological Bulletin, 103 (3): 411-423.

Artar, Y. ve Karabacakoğlu, Ç. (2003). Türkiye'de Özürlüler Turizminin Geliştirilmesine Yönelik Olarak Konaklama Tesislerindeki Alt Yapı Olanaklarının Araştırılması. Ankara: Milli Prodüktivite Merkezi. 
Baloğlu, S. (1999). A Path Analytic Model of Visitation Intention Involving Information Sources, Socio-Psychological Motivations and Destination Images, Journal of Travel and Tourism Marketing, 8 (3): 81-90.

Bi, Y., Card, J. A. ve Cole, S. T. (2007). Accessibility and Attitudinal Barriers Encountered by Chinese Travelers with Physical Disabilities, International Journal of Tourism Research, 9: 205-216.

Bign J., Sanchez, M. ve Sanchez, J. (2001). Tourism Image, Evaluation Variables and After Purchase Behavior: Inter-Relationships, Tourism Management, 22 (6): 607-616.

Burnett, J. J. ve Baker, H. B. (2001). Assessing the Travel Related Behaviors of the Mobility-Disabled Consumer, Journal of Travel Research, 40: 4-11.

Carroll, B. ve Alexandris, K. (1997). Perception of Constraints and Strength of Motivation: Their Relation to Recreational Sport Participation, Journal of Leisure Research, 29: 279-299.

Cavinato, J. L. ve Cuckovich, M. L. (1992). Transportation and Tourism for the Disabled: An Assessment, Transportation Journal, 31 (3): 46-53.

Chau, P. Y. K. (1997). Reexamining a Model for Evaluating Information Center Success Using a Structural Equation Modeling Approach, Decision Sciences, 28 (2): 309-334.

Crawford, D. W. ve Godbey, G. (1987). Reconceptualizing Barriers to Family Leisure, Leisure Sciences, 9 (2): 119-128.

Crawford, D. W., Jackson, E. L. ve Godbey, G. (1991). A Hierarchical Model of Leisure Constraints, Leisure Sciences, 13 (4): 309-320.

Crawford, D. ve Godbey, G. (1987). Reconceptualizing Barriers to Family Leisure, Leisure Sciences, 9: 119-127.

Daniels, M. J., Rodgers, E. D. ve Wiggins, B. P. (2005). “Travel Tales": An Interpretive Analysis of Constraints and Negotiations to Pleasure Travel as Experienced by Persons with Physical Disabilities, Tourism Management, 26 (6): 919-930.

Darcy, S. (2002). Marginalized Participation: Physical Disability, High Support Needs and Tourism, Journal of Hospitality and Tourism Management, 9 (1): 61-72.

Deci, E. L. ve Ryan, R. M. (2000). The 'what' and 'Why' of Goal Pursuits: Human Needs and The Self-Determination of Behavior, Psychological Inquiry, 11: 227-268.

Fleischer, A. ve Seiler, E. (2002). Determinants of Vacation Travel Among Israeli Seniors: Theory and Evidence, Applied Economics, 34: 421-430.

Fornell, C. ve Larkner, D. F. (1981). Evaluating Structural Equation Models With Unobservable Variables and Measurement Error, Journal of Marketing Research, 18: 39-50.

Gilbert, D. ve Hudson, S. (2000). Tourism Demand Constraints: A Skiing Participation, Annals of Tourism Research, 27: 906-925.

Gladwell, N. Y. ve Bedini, L. A. (2004). In Search of Lost Leisure: The Impact of Care Giving on Leisure Travel, Tourism Management, 25: 685-693.

Gnoth, J. (1997). Tourism Motivation and Expectation Formation, Annals of Tourism Research, 24 (2): 283-304.

Hair, J. F., Black, W. C., Babin, B. J., Anderson, R. E., ve Tatham, R. L. C. (2006). Multivariate Data Analysis With Readings. 6. Baskı. New Jersey: Prentice Hall.

Hinch, T. ve Jackson, E. (2000). Leisure Constraints Research: Its Value as a Framework For Understanding Tourism Seasonality, Current Issues in Tourism, 3: 87-106.
Hubbard, J. ve Mannell, R. (2001). Testing Competing Models of The Leisure Constraint Negotiation Process in a Corporate Employee Recreation Setting, Leisure Sciences, 23 (3): 145-163.

Israeli, A. A. (2002). A Preliminary Investigation of The Importance of Site Accessibility Factors for Disabled Tourists, Journal of Travel Research, 41 (1): 101-104.

Jackson, E. L. (1993). Recognizing Patterns of Leisure Constraints: Results From Alternative Analyses, Journal of Leisure Research, 25: 129-149.

Jackson, E. L., Crawford, D. W., ve Godbey, G. (1993). Negotiations of Leisure Constraints, Leisure Sciences, 15: 1-11.

Kay, T. ve Jackson, G. (1991). Leisure Despite Constraint: The Impact of Leisure Constraints on Leisure Participation, Journal of Leisure Research, 23: 301-313.

Lee, B. K., Agarwal, S. ve Kim, H. J. (2011). Influences of Travel Constraints on The People With Disabilities' Intention to Travel: An Application of Seligman's Helpness Theory, Tourism Management, 33: 569-579.

Maslow, A. H. (1943). A Theory of Human Motivation, Psychological Review, 50: 370-396.

McKercher, B., Packer, T., Yau, M.K., ve Lam, P. (2003). Travel Agents as Facilitators or Inhibitors of Travel: Perceptions of People with Disabilities, Tourism Management, 24: 465-474.

Nunnally, J. C. (1978). Psychometric Theory. 2. Baskı. New York: McGraw-Hill.

Nyaupane, G. P., Morais, D. B., ve Graefe, A. R. (2004). Nature Tourism Constraints: A Cross-Activity Comparison, $\mathrm{A} n$ nals of Tourism Research, 31 (3): 540-555.

Özdamar, K. (2004). Paket Programlar ile İstatistiksel Veri Analizi, (Çok Değişkenli Analizler) Eskişehir: Kaan Kitabevi.

Öztürk, Y., Yaylı, A. ve Yeşiltaş, M. (2008). Is The Turkish Tourism Industry Ready for a Disabled Customer's Market?, Tourism Management, 29 (2): 38289.

Pearce, P. L. (2005). Tourist Behaviour: Themes and Conceptual Schemes. Ontario: Channel View Publication.

Sirakaya, E., Petrick, J. ve Choi, H. S. (2004). The Role of Mood on Tourism Product Evaluation, Annals of Tourism Research, 31 (3): 517-539.

Seligman, M. E. (1975). Helplessness: On Depression, Development and Death. San Francisco: W.H. Freeman.

Shaw, G. ve Coles, T. (2004). Disability, Holiday-Making and The Tourism Industry in the U.K.: A Preliminary Survey, Tourism Management, 25: 397-403.

Smith, R. W. (1987). Leisure of Disabled Tourists: Barriers to Travel, Annals of Tourism Research, 14 (3): 376-389.

Son, J., Mowen, A. ve Kerstetter, D. (2008). Testing Alternative Leisure Constraint Negotiation Models: An Extension of Hubbard and Mannell's Study, Leisure Sciences, 30: 198-216.

Stalp, M. (2006). Negotiating Time and Space for Serious Leisure: Quilting in the Modern U.S. Home, Journal of Leisure Research, 38 (1): 104-113.

Şimşek, Ö. F. (2007). Yapısal Eşitlik Modellemesine Giriş, Temel İlkeler ve Lisrel Uygulamaları. Ekinoks Yayınları, Ankara.

Yau, M. K., McKercher, B. ve Packer, T.L. (2004). Traveling with Disability: More Than an Access Issue, Annals of Tourism Research, 31 (4): 946-960. 